\section{Effect of four levels of shade on survival, morphology and chlorophyll fluorescence of Nothofagus alessandrii container-grown seedlings}

\author{
Rómulo Santelices, Sergio Espinoza, Antonio María Cabrera
}

\begin{abstract}
Nothofagus alessandrii (ruil) is a threatened, endemic tree of the Mediterranean zone of Chile. As a result of past anthropogenic activities, its current cover has been reduced to only 314 hectares across several fragmented and degraded areas. Although activities to conserve and recover such forests have been developed, little is known about their propagation and nursery cultivation, since the plant's quality is one of the most important factors for restoration and reforestation plans, re-vegetation, or forest enrichment. The success of restoration programs in these areas will require improvements in plant production, being important to test the shade effects on seedling survival and growth. This paper reports the results of testing for survival, morphological and chlorophyll fluorescence differences in N. alessandrii seedlings grown for approximately 32 weeks in unshaded conditions and under three different levels of shading $(18 \%, 50 \%$, and $80 \%$ shade). Morphological traits (stem height, root collar diameter, specific leaf area, shoot and root biomass, and quality indexes) and survival were measured. Chlorophyll fluorescence was also measured to analyze the shade tolerance of the species. Analysis showed significant differences for most traits as a consequence of the shade level. Seedlings exposed to $18 \%$ shade showed the highest total dry biomass, while those exposed to $80 \%$ shade showed the highest survival rate $(92 \%)$. Chlorophyll fluorescence was high in the unshaded conditions and medium in the $18-50 \%$ shade. Morphological and chlorophyll fluorescence responses differed greatly among shade levels and corresponded with the degree of shade tolerance of the species.
\end{abstract}

Keywords: Seedling, Ruil, Early Growth, Shadow

\section{Introduction}

Nothofagus alessandrii Espinosa (ruil) is a threatened and endemic tree of the Mediterranean zone of Chile (UICN 2001). At the beginning of the last century, ruil forests have been subjected to logging and burning to clear land for cultivation (Donoso \& Landaeta 1983), leaving the remnant populations highly fragmented and surrounded by Pinus radiata D. Don plantations (Bustamante \& Castor 1998). Current anthropogenic pressures on ruil forests led to consider such

species as one of the most threatened trees in Chile. Today, the total area of ruil forests covers only 314 ha, decreasing by $11.8 \%$ in last 17 years (Santelices et al. 2012).

The restoration of these forest ecosystems is a priority task, and calls for a better understanding of the factors that improve the seedling quality. However, in Chile, local authorities are still in the process of policy formulation, and there is no national recovering policy for the species. Besides, little information is available about the seedling

Universidad Católica del Maule, Centro de Desarrollo del Secano Interior, Avenida San Miguel 3605, Talca (Chile)

@ Rómulo Santelices (rsanteli@ucm.cl)

Received: Apr 23, 2014 - Accepted: Oct 06, 2014

Citation: Santelices R, Espinoza S, Cabrera AM, 2015. Effects of four levels of shade on survival, morphology and chlorophyll fluorescence of Nothofagus alessandrii containergrown seedlings. iForest 8: 638-641 [online 2015-01-08] URL: http://www.sisef.it/iforest/ contents/?id=ifor1321-007

Communicated by: Gianfranco Minotta cultivation of N. alessandrii (Santelices et al. 2011a, 2011b).

It is recognized that seedlings of this species grow under the protection of adult trees and shaded by the understory. Shading is an important cultural practice for seedling quality and survival, especially for seedlings to be established in Mediterranean climate regions (Vázquez de Castro et al. 2014).

The importance of shading for the development of Nothofagus genus species, including ruil, has been already reported (Santelices et al. 1995, 2011a, 2011b), and the shade-cloth method is widely used to protect plants from direct radiation (Landis et al. 1995). Shade promotes the development of morphological traits (Santelices et al. 2011a) and induces physiological responses in ruil nursery seedlings. However, no studies have examined the effects of shade on physiological response of N. alessandrii so far. Chlorophyll fluorescence has been increasingly used to understand both the mechanism of photosynthesis and the factors affecting it. Vidaver et al. (1989) suggested that chlorophyll fluorescence can rapidly provide useful information about photosynthetic responses to environmental stresses.

The objective of this study was to evaluate the effects of three different shade levels and unshaded conditions on the survival, morphology, and chlorophyll fluorescence of $N$. alessandrii seedlings cultivated in containers. The study assessed the hypothesis that $N$. alessandrii seedlings require some degree of protection from direct sunlight in their early stages of development.

\section{Materials and Methods}

\section{Plant material}

The N.alessandrii seeds were collected in a natural stand near the locality Lo Ramirez, Curepto Commune $\left(35^{\circ} 10^{\prime} \mathrm{S}, 72^{\circ} 06^{\prime} \mathrm{W}\right.$, elevation $385 \mathrm{~m}$ a.s.1.), which is located in the province of Talca, Maule Region, Central Chile. Fruits were collected directly from the branches and transported to the nursery at the Catholic University del Maule (Talca, Chile). Seeds were cleaned and weighed according to the ISTA (2006) standards.

The seeds were then sown in rigid plastic containers of $140 \mathrm{ml}$ (Termomatrices ${ }^{\circledR}$, Santiago, Chile) at an approximate depth of 0.5 $\mathrm{cm}$. The substrate consisted of a mixture of composted bark of Pinus radiata and perlite (7:3 ratio), which was combined with the slow-release fertilizer Basacote ${ }^{\circledR} 9 \mathrm{M}$ (COM$\mathrm{PO} \mathrm{GmbH} \& \mathrm{Co}$. KG, Munster, Germany $16 \% \mathrm{~N}, 8 \% \mathrm{P}_{2} \mathrm{O}_{5}, 12 \% \mathrm{~K}_{2} \mathrm{O}, 12 \% \mathrm{SO}_{3}, 2 \%$ $\mathrm{MgO}, 0.02 \% \mathrm{~B}, 0.05 \% \mathrm{Cu}, 4 \% \mathrm{Fe}$ and $0.06 \%$ $\mathrm{Mn}$ ), at a dose of $3 \mathrm{~g} \mathrm{~L}^{-1}$ of substrate. During their cultivation and before the shade treatments, seedlings were protected by a plastic mesh sunshade (Raschel ${ }^{\circledR}$, Yantai Sanhai In- 
Tab. 1 - Effect of shading on morphological attributes of container-grown $N$. alessandrii seedlings. Mean values with the same letter are not significantly different ( $>0.05)$ after Tukey's test. (PAR): photosynthetically active radiation; $(S L A)$ : Specific leaf area; $(L)$ : length of the stem; $(D)$ : root collar diameter.

\begin{tabular}{cccccccc}
\hline $\begin{array}{c}\text { Shading } \\
(\mathbf{\%})\end{array}$ & $\begin{array}{c}\text { PAR } \\
(\mathbf{\%})\end{array}$ & $\begin{array}{c}\boldsymbol{D} \\
(\mathbf{m m})\end{array}$ & $\begin{array}{c}\boldsymbol{L} \\
(\mathbf{c m})\end{array}$ & $\begin{array}{c}\boldsymbol{S L A} \\
\left(\mathbf{c m}^{2} \mathbf{g}^{-1}\right)\end{array}$ & Shoot & \multicolumn{2}{c}{ Biomass $(\mathbf{g})$} \\
\hline 0 & 100 & $2.9 \pm 0.14^{\mathrm{a}}$ & $14.3 \pm 0.95^{\mathrm{b}}$ & $143.2 \pm 7.9^{\mathrm{b}}$ & $1.52 \pm 0.14^{\mathrm{ab}}$ & $0.83 \pm 0.14^{\mathrm{b}}$ & $2.35 \pm 0.16^{\mathrm{ab}}$ \\
18 & 45 & $3.0 \pm 0.13^{\mathrm{a}}$ & $16.4 \pm 1.02^{\mathrm{b}}$ & $140.3 \pm 7.3^{\mathrm{b}}$ & $2.19 \pm 0.49^{\mathrm{a}}$ & $1.41 \pm 0.12^{\mathrm{a}}$ & $3.60 \pm 0.54^{\mathrm{a}}$ \\
50 & 41 & $2.4 \pm 0.09^{\mathrm{b}}$ & $13.2 \pm 0.87^{\mathrm{c}}$ & $159.2 \pm 14.2^{\mathrm{b}}$ & $1.20 \pm 0.15^{\mathrm{b}}$ & $0.83 \pm 0.13^{\mathrm{b}}$ & $2.03 \pm 0.12^{\mathrm{b}}$ \\
80 & 20 & $3.0 \pm 0.10^{\mathrm{a}}$ & $21.7 \pm 1.11^{\mathrm{a}}$ & $235.0^{\mathrm{b}} \pm 6.8^{\mathrm{a}}$ & $1.54 \pm 0.14^{\mathrm{ab}}$ & $0.80 \pm 0.08^{\mathrm{b}}$ & $2.34 \pm 0.21^{\mathrm{b}}$ \\
\hline
\end{tabular}

dustry Ltd., Shandong, China).

\section{Shade treatments}

The study used a completely randomized blocks design: 3 blocks, 3 shade treatments and 20 seedlings per treatment. Seedlings were grown either under full sun or under shade-cloth shelters. The shading treatments applied were: (i) unshaded conditions, which received $100 \%$ of the photosynthetically active radiation (PAR); (ii) $18 \%$ shade $(45 \%$ PAR); (iii) $50 \%$ shade ( $41 \%$ of PAR); and (iv) $80 \%$ shade (20\% PAR). PAR emissions in each treatment were induced by using the EARS PPM200 portable pulse-modulated fluorometer (EARS, Delft, the Netherlands), in which adaptation to dark is not required for certain measurements. During their germination seedlings were watered daily using micro-sprinklers. After seedlings emergence, the substrate was maintained at field capacity by weighing the pots three times per week and adding amounts of water equal to the loss in weight. Seedlings were grown for approximately 32 weeks.

\section{Morphological measurements}

The morphological traits measured were: stem length $(L)$, root collar diameter $(D)$, aboveground biomass (stem + leaves, $A B$ ), root biomass $(R B)$, and total biomass $(T B)$.
Starting since eight weeks after sowing and until the end of the experiment, all seedlings were measured for $L$ and survival at 2-week intervals. Survival was measured according to a categorical scale $(1=$ alive, $0=$ dead $)$. To determine biomass, nine seedlings per treatment and replication were randomly selected $(9$ seedlings $\times 4$ treatments $\times 3$ replicates $=108$ seedlings). Several indexes were calculated as follows: the slenderness index $(S I)$, the shoot:root index (SRI - Iverson $1984)$ and the Dickson's index (DI - Dickson et al. 1960), according to the following formulas (eqn. 1 , eqn. 2 , eqn. 3 ):

$$
\begin{gathered}
S I=\frac{L(\mathrm{~cm})}{D(\mathrm{~mm})} \\
S R I=\frac{A B(\mathrm{~g})}{R B(\mathrm{~g})} \\
D I=\frac{T B(\mathrm{~g})}{[L(\mathrm{~cm}) / D(\mathrm{~mm})]+[A B(\mathrm{~g}) / R B(\mathrm{~g})]}
\end{gathered}
$$

Specific leaf area $\left(S L A, \mathrm{~cm}^{2} \mathrm{~g}^{-1}\right)$, i.e., the ratio of foliar surface to dry weight, was also estimated. For this purpose, five seedlings per treatment were randomly selected, and three leaves per plant were sampled ( 5 seedlings $\times 4$ treatments $\times 3$ leaves). Leaves were scanned using a common desk-top scanner

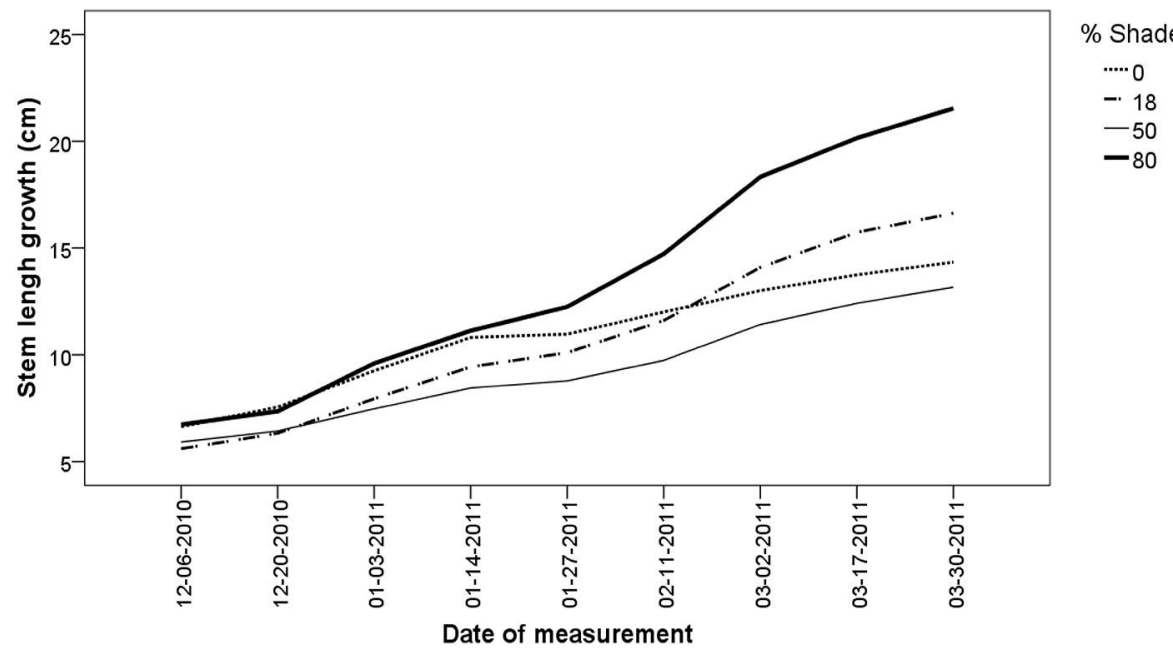

Fig. 1 - Stem length of $N$. alessandrii seedlings exposed at three shade levels and to unshaded conditions over 32 weeks.
(Hewlett-Packard, Cupertino, CA, USA) and the surface was measured by using a digital planimeter (Tamaya, Tokyo, Japan). To determine the foliar dry weight, the samples were oven-dried at $60{ }^{\circ} \mathrm{C}$ for $48 \mathrm{~h}$ in a convection oven (Memmert, Germany) and then weighed with a precision balance (Boeco, Germany).

\section{Chlorophyll fluorescence measurements}

Chlorophyll fluorescence $(F)$ was measured in five seedlings per treatment with an EARS PPM200 portable pulse-modulated fluorometer $(5$ seedlings $\times 4$ treatments $\times 3$ blocks $=60$ seedlings). A portion of branches and terminal shoot of each seedling was placed in the fluorometer sphere and illuminated to $100 \mathrm{mmol} \mathrm{m}^{-2} \mathrm{sec}^{-1}$. All measurements were performed between 09:00 and 15:00 hours.

\section{Experimental design and statistical analysis}

Vertical and lateral shade was ensured for every shading treatment, and a three-meter buffer between shade treatments was maintained in order to avoid light or shade overlap. Stem length data measured over time were subjected to the repeated measures analyses procedure, while all other variables were analyzed by the analysis of variance (ANOVA). Pairwise comparisons of survival between groups were done using a Chisquare test. To satisfy model assumptions, data for biomass (i.e., shoots, roots and shoot:root ratio) were log-transformed. The analysis of variance and the comparisons of means were performed using the general linear model (GLM) procedure implemented in the software package SPSS $^{\circledR}$ ver. 18 for Windows ${ }^{\circledR}$. Differences among mean values were tested by the post-hoc Tukey's test ( $\alpha=$ $0.05)$.

\section{Results}

Shading resulted in significant differences in all morphological traits (Tab. 1). $L$ differed significantly over time among shade treatments $(\mathrm{p}<0.001)$, being higher under $80 \%$ shade and lower under $50 \%$ shade treatments (Fig. 1). Seedlings exposed to $18 \%$ shade showed the highest shoot and root biomass, while the seedlings exposed to $80 \%$ 
Tab. 2 - Effect of shading on quality indexes, survival and chlorophyll fluorescence of container-grown $N$. alessandrii seedlings. Mean values with the same letter are not significantly different ( $p>0.05)$ after Tukey's test. (PAR): photosynthetically active radiation; (F); chlorophyll fluorescence.

\begin{tabular}{|c|c|c|c|c|c|c|}
\hline \multirow{2}{*}{$\begin{array}{c}\text { Shading } \\
(\%)\end{array}$} & \multirow{2}{*}{$\begin{array}{c}\text { PAR } \\
(\%)\end{array}$} & \multirow{2}{*}{$\begin{array}{c}\text { Survival } \\
(\%)\end{array}$} & \multirow{2}{*}{$\begin{array}{c}\mathrm{F}(\mu \mathrm{mol} \\
\left.\text { photons } \mathbf{m}^{-2} \mathbf{s}^{-1}\right)\end{array}$} & \multicolumn{3}{|c|}{ Quality indexes } \\
\hline & & & & Slenderness & Shoot:root & Dickson \\
\hline 0 & 100 & $60^{\mathrm{c}}$ & $2922 \pm 138.9^{c}$ & $5.2 \pm 0.65^{b}$ & $2.0 \pm 0.76^{b}$ & $0.34 \pm 0.04^{\mathrm{ab}}$ \\
\hline 18 & 45 & $73^{b}$ & $2437 \pm 101.2^{b}$ & $6.5 \pm 0.46^{\mathrm{ab}}$ & $1.6 \pm 0.32^{b}$ & $0.45 \pm 0.07^{\mathrm{a}}$ \\
\hline 50 & 41 & $77^{b}$ & $2373 \pm 142.8^{b}$ & $7.0 \pm 0.50^{\mathrm{ab}}$ & $1.6 \pm 0.29^{b}$ & $0.24 \pm 0.14^{b}$ \\
\hline 80 & 20 & $92^{\mathrm{a}}$ & $1406 \pm 85.4^{\mathrm{a}}$ & $8.1 \pm 0.44^{\mathrm{a}}$ & $2.3 \pm 0.13^{\mathrm{a}}$ & $0.24 \pm 0.02^{b}$ \\
\hline
\end{tabular}

shade were the tallest. As the shade level increased, seedlings tended to be significantly more slender, with higher SLA (Tab. 2). It is noteworthy to mention that seedlings exposed to $18 \%$ shade had the better quality according to their mean $D I$ values. Survival also differed according to the shade treatment. As expected, the lower survival was found in $0 \%$ shade treatment. Chlorophyll fluorescence increased as seedlings were exposed to higher lighting conditions.

\section{Discussion}

\section{Effects of light and shade on survival and morphological responses of $N$. alessandrii}

The growth rate of $N$. alessandrii in this study could be considered low with respect to Santelices et al. (2011b), who reported $L$ values ranging from 28 to $32 \mathrm{~cm}$ and $D$ values of $4 \mathrm{~mm}$ in containerized seedlings grown in $140 \mathrm{ml}$ pots and exposed to 35 and $50 \%$ shade. The largest $D$ growth was achieved by increasing light intensity, being clear that the light intensity influences nursery seedling growth. The results of this study agree with those of Santelices et al. (2011b), indicating that a shadow treatment that allows about $40 \%$ PAR could optimize $N$. alessandrii nursery growth.

As the seedlings received less PAR, there was an increase in SLA, which reinforces the need to provide shade in the early stages of ruil development. In Fagus sylvatica L. both an increase and a decrease in specific leaf weight and dry weights were observed, while there was an increase in light intensity (Minotta \& Pinzauti 1996, Ammer 2003). The results of this study are in part similar to that reported by Ammer (2003), who observed a decrease of SLA with increasing light intensity, and may be related to factors such as the origin of seeds and the degree of adaptability to light conditions in their natural distribution area.

A plant exposed to low light intensity will allocate more biomass to stems and leaves (i.e., shoots), consequently increasing its shoot:root ratio (McConnagughay \& Coleman 1999). This behavior was observed in the $20 \%$ PAR treatment. However, plants with a high shoot:root ratio show also some drawbacks, as they consume more water than plants with a low shoot:root ratio. The lower the ratio of these two components, the greater the chance of plant survival (Poorter \& Nagel 2000), especially in dry areas (Navarro-Cerrillo et al. 2006).

The results of the $D I$ estimation shows that seedlings exposed to $18 \%$ shade had a better quality, mainly because the above index combines the SI and SRI, thereby observing a greater $T B$ in seedlings exposed to $18 \%$ shade level according to Chirino et al. (2008). In the case of SRI, Navarro-Cerrillo et al. (2006) recommended a ratio close to the unit to ensure good survival in the early establishment of $Q$. ilex. In this study seedlings exposed to $18-50 \%$ shade showed more balanced $S R I$ values (mean: 1.6).

In the present study, differences in $F$ were observed among treatments. The unshaded treatment showed the highest values for this variable, which indicates that $N$. alessandrii needs protection from direct sunlight in its early stages of development. The $20 \%$ PAR treatment had the lowest $F$ values, indicating a low level of light stress and a coincidence with the biomass allocation analysis (i.e., $S R I$ ) and also with the survival analysis. Indeed, the lack of light is the limiting factor in this treatment, and the plant allocates more biomass to the shoots at the expense of the roots. Seedling survival decreases with light, which is consistent with studies on other Nothofagus species (Martínez-Pastur et al. 2007, Coopman et al. 2008, Reyes-Días et al. 2009), where an improved survival at low light intensities was observed.

Our results show that the SLA is related to $F$, because in the lower light intensity treatment $(20 \%$ of the PAR), the leaves became wider, which could indicate a high efficiency by $N$. alessandrii to capture and use limited amounts of light and then consume carbohydrates efficiently. This efficiency could be explained in part by the high SLA and SRI observed with that level of light intensity. A high SLA implies a greater number of chloroplasts and enzymes and an improved pho-

\section{Ecophysiological responses of $N$. alessandrii to shade increase}

tosynthetic capacity per unit leaf area (Evans \& Poorter 2001).

\section{Conclusions}

This study has shown that the shade level affects the morphological and chlorophyll response of container-grown $N$. alessandrii seedlings. Although the uniform shade environments created with shade-cloth in this study are not representative of the fluctuating light conditions occurring in the forest, our results indicate that $N$. alessandrii seedlings performed poorly in full sunlight (100\% PAR), while with moderate shade (41-50\% PAR), a better development is achieved (improved SI and DI). Chlorophyll fluorescence was inversely related to shade, probably indicating that photochemical efficiency of $N$. alessandrii was lower under full sunlight. These findings have considerable implications for ecosystem management. However, results of this study should be interpreted with caution, since the seedling response to shade may differ in diverse field conditions as a consequence of other environmental factors.

\section{Acknowledgements}

We are indebted with Dr. Anne Bliss, from the University of Colorado at Boulder $(\mathrm{CO}$, USA), for her valuable corrections of English. Many thanks to Daniela Sánchez and Daniela Muñoz for data collection. We also thank the Universidad Católica del Maule (Talca, Chile) for funding this research.

\section{References}

Ammer CH (2003). Growth and biomass partitioning of Fagus sylvatica L. and Quercus robur L. seedlings in response to shading and small changes in the R/FR-ratio of radiation. Annals of Forest Science 60: 163-171. - doi: 10.1051/forest:2003009

Bustamante R, Castor C (1998). The decline of an endangered temperate ecosystem: the ruil ( $\mathrm{No}$ thofagus alessandrii) forest in central Chile. Biodiversity and Conservation 7: 1607-1626. doi: 10.1023/A:1008856912888

Chirino E, Vilagrosa A, Hernández EI, Matos A, Vallejo VR (2008). Effects of a deep container on morpho-functional characteristics and root colonization in Quercus suber L. seedlings for reforestation in Mediterranean climate. Forest Ecology and Management 256: 779-785. - doi: 10.1016/j.foreco.2008.05.035

Coopman RE, Reyes-Díaz M, Briceño VF, Corcuera LJ, Cabrera HM, Bravo LA (2008). Changes during early development in photosynthetic light acclimation capacity explain the shade to sun transition in Nothofagus nitida. Tree Physiology 28: 1561-1571. - doi: 10.1093/ treephys/28.10.1561

Dickson A, Leaf AL, Hosner IE (1960). Quality appraisal of white spruce and white pine seedlings stock in nurseries. Forestry Chronicle 36: 10-13. - doi: 10.5558/tfc36010-1 
Donoso C, Landaeta E (1983). Ruil (Nothofagus alessandrii), a threatened Chilean tree species. Environmental Conservation 10: 159-162. - doi: 10.1017/S0376892900012273

Evans JR, Poorter H (2001). Photosynthetic acclimation of plants to growth irradiance: the relative importance of specific leaf area and nitrogen partitioning in maximizing carbon gain. Plant, Cell and Environment 24: 755-767. - doi: 10.104 6/j.1365-3040.2001.00724.x

ISTA (2006). International rules for seed testing (2006 edn). International Seed Testing Association (ISTA), Bassersdorf, Switzerland.

Iverson RD (1984). Planting stock selection: meeting biological needs and operational realities. In "Forest nursery manual" (Duryea ML, Landis TD eds). Oregon State University, Corvallis, USA, pp. 261-266. - doi: 10.1007/978-94-0096110-4_24

Landis TD, Tinus RW, McDonald SE, Barnett JP (1995). Nursery planning, development, and management. Vol. 1. The container tree nursery manual. Agricultural Handbook 674, USDA Forest Service, Washington, DC, USA, pp. 188. Martínez-Pastur G, Lencinas MV, Peri PL, Arena M (2007). Photosynthetic plasticity of Nothofagus pumilio seedlings to light intensity and soil moisture. Forest Ecology and Management 243: 274-282. - doi: 10.1016/j.foreco.2007.03.034

McConnagughay K, Coleman J (1999). Biomass allocation in plants: ontogeny or optimality? A test along three resources gradients. Ecology 80: 2581-2593. - doi: 10.1890/0012-9658(1999)080 [2581:BAIPOO]2.0.CO;2

Minotta G, Pinzauti S (1996). Effects of light and soil fertility on growth, leaf chlorophyll content and nutrient use efficiency of beech (Fagus sylvatica L.) seedlings. Forest Ecology and Mana- gement 86 (1-3): 61-71. - doi: 10.1016/S03781127(96)03796-6

Navarro-Cerrillo R, Villar-Salvador P, Del Campo A (2006). Morfología y establecimiento de los plantones [Seedling morpholgy and establishment]. In: "Calidad de planta forestal para la restauración en ambientes mediterráneos, estado actual de conocimientos" (Cortina J, Peñuelas JL, Puértolas J, Savé R, Vilagrosa A eds). Ministerio del Medioambiente, Dirección general para la biodiversidad, Madrid, Spain, pp. 67-88. [in Spanish]

Poorter H, Nagel O (2000). The role of biomass allocation in the growth response of plants to different levels of light, $\mathrm{CO}_{2}$, nutrients and water: a quantitative review. Australian Journal of Plant Physiology 27 (12): 1191. - doi: 10.1071/PP991 $73 \mathrm{CO}$

Reyes-Días M, Ivanov AG, Huner NPA, Alberdi M, Corcuera LJ, Bravo LA (2009). Thermal energy dissipation and its components in two developmental stages of a shade-tolerant species, Nothofagus nitida, and a shade-intolerant species, Nothofagus dombeyi. Tree Physiology 29: 651-662. - doi: 10.1093/treephys/tpp003

Santelices R, Herrera L, Osores J (1995). Cultivo en vivero del hualo (Nothofagus glauca (Phil.) Krasser) bajo diferentes gradientes de luminosidad y espaciamiento [Nursery cultivation of Hualo (Nothofagus glauca (Phil.) Krasser) under different levels of light and stocking]. Ciencia Forestal 10 (1-2): 3-13. [in Spanish] [online] URL: http:/www.revistacienciasforestales.uchi le.cl/1995_vol10/n1-2a01.pdf

Santelices R, Navarro-Cerrillo RM, Drake F (2011a). Propagation and seedling cultivation of the endemic species Nothofagus alessandrii Espinosa in Central Chile. Restoration Ecology 19:
177-185. - doi: 10.1111/j.1526-100X.2009.0055 $0 . x$

Santelices R, Navarro-Cerrillo RM, Drake F, Mena C (2011b). Efecto de la cobertura y de la fertilización en el desarrollo de plantas de Nothofagus alessandrii cultivadas en contenedor [Effect of cover and fertilization on the early development of Nothofagus alessandrii nursery container seedlings]. Bosque 32: 85-88. [in Spanish] - doi: 10.4067/S0717-92002011000100 010

Santelices R, Drake F, Navarro-Cerrillo RM (2012). Establishment of a Nothofagus alessandrii plantation using different levels of shade and weed control methods in Talca province, central Chile. Southern Forest 74: 71-76. - doi: 10.2989/ 20702620.2012 .686215

UICN (2001). Categorías y criterios de la lista roja de la Unión Internacional para la conservación de la naturaleza y los recursos naturales (UICN) [IUCN red list categories and criteria for conservation of nature and natural resources]. Versión 3.1, Comisión de supervivencia de especies. Gand, Suiza y Cambridge, UK, pp. 33. [in Spanish]

Vidaver W, Binder W, Brooke RC, Lister GR, Toivonen PMA (1989). Assessment of photosynthetic activity of nursery grown Picea glauca seedlings using an integrated fluorometer to monitor variable chlorophyll fluorescence. Canadian Journal of Forest Research 19: 1478-1482. - doi: 10.1139/x89-224

Vázquez de Castro A, Oliet JA, Puértolas J, Jacobs DF (2014). Light transmissivity of tube shelters affects root growth and biomass allocation of Quercus ilex L. and Pinus halepensis Mill. Annals of Forest Science 71: 91-99. - doi: 10.1007/s13595-013-0335-3 